\title{
Detection and genomic characterization of hepatitis $E$ virus genotype 3 from pigs in Ghana, Africa
}

Philip El-Duah 1,2, Dickson Dei ${ }^{3,4}$, Tabea Binger ${ }^{2}$, Augustina Sylverken ${ }^{2,5}$, Robert Wollny ${ }^{6}$, William Tasiame ${ }^{1,4}$, Samuel Oppong ${ }^{7}$, Yaw Adu-Sarkodie ${ }^{8}$, Benjamin Emikpe ${ }^{4}$, Raphael Folitse ${ }^{4}$, Jan Felix Drexler ${ }^{1}$, Richard Phillips ${ }^{2}$, Christian Drosten ${ }^{1,9}$ and Victor Max Corman ${ }^{1,9^{*}}$ [D

\begin{abstract}
Background: Hepatitis E virus (HEV) is a major cause of human hepatitis worldwide. Zoonotic genotypes of the virus have been found in diverse animal species with pigs playing a major role. Putative risk of zoonotic infection from livestock particularly swine in Sub-Saharan Africa including Ghana is poorly understood due to scarcity of available data, especially HEV sequence information.

Methods: Serum samples were collected from cattle, sheep, goats and pigs from Kumasi in the Ashanti region of Ghana. Samples were subjected to nested RT-PCR screening and quantification of HEV RNA-positive samples using real-time RT-PCR and the World Health Organization International Standard for HEV. Testing of all pig samples for antibodies was done by ELISA. Sanger sequencing and genotyping was performed and one representative complete genome was generated to facilitate genome-wide comparison to other available African HEV sequences by phylogenetic analysis.
\end{abstract}

Results: A total of 420 samples were available from cattle $(n=105)$, goats $(n=124)$, pigs $(n=89)$ and sheep $(n=102)$. HEV Viral RNA was detected only in pig samples (10.1\%). The antibody detection rate in pigs was $77.5 \%$, with positive samples from all sampling sites. Average viral load was $1 \times 10^{5}$ (range $1.02 \times 10^{3}$ to $3.17 \times 10^{5}$ ) International Units per $\mathrm{mL}$ of serum with no statistically significant differences between age groups ( $\leq 6$ month, $>6$ months) by a T-test comparison of means $(t=1.4272, d f=7, p=0.1966)$. Sequences obtained in this study form a monophyletic group within HEV genotype 3 . Sequences from Cameroon, Ghana, Burkina Faso and Madagascar were found to share a most recent common ancestor; however this was not the case for other African HEV sequences.

Conclusion: HEV genotype 3 is highly endemic in pigs in Ghana and likely poses a zoonotic risk to people exposed to pigs. HEV genotype 3 in Ghana shares a common origin with other virus strains from Sub-Saharan Africa.

Keywords: Foodborne diseases, One health, Zoonoses, Livestock, Infectious disease reservoirs, Viral hepatitis

\footnotetext{
* Correspondence: Victor.corman@charite.de

${ }^{1}$ Charité-Universitätsmedizin Berlin, Humboldt-Universität zu Berlin, Berlin

Institute of Health, Institute of Virology, Berlin, Germany

${ }^{9}$ German Centre for Infection Research, Berlin, Germany

Full list of author information is available at the end of the article
}

(c) The Author(s). 2020 Open Access This article is licensed under a Creative Commons Attribution 4.0 International License, which permits use, sharing, adaptation, distribution and reproduction in any medium or format, as long as you give appropriate credit to the original author(s) and the source, provide a link to the Creative Commons licence, and indicate if changes were made. The images or other third party material in this article are included in the article's Creative Commons licence, unless indicated otherwise in a credit line to the material. If material is not included in the article's Creative Commons licence and your intended use is not permitted by statutory regulation or exceeds the permitted use, you will need to obtain permission directly from the copyright holder. To view a copy of this licence, visit http://creativecommons.org/licenses/by/4.0/. 


\section{Background}

Hepatitis E virus (HEV) is a major cause of hepatitis in humans worldwide. HEV is a single stranded RNA virus with a genome size of approximately $7.2 \mathrm{~kb}$. According to the International Committee on Taxonomy of viruses (ICTV), it is classified into the family Hepeviridae. Most of the HEV strains infecting humans belong to the virus species Orthohepevirus A (Genus Orthohepevirus), which comprise eight genotypes (gt), of which 1 to 4 and 7 have been found in humans. Genotypes 1 and 2 seem to be restricted to humans while the other three human genotypes are zoonotic and occur in other animals, including pigs (gt3-6), rabbits (gt3) and camelids (gt7) [1-4]. HEV gt1 and gt 2 are transmitted faeco-orally and have been responsible for outbreaks in low socioeconomic settings, particularly in Africa [5, 6]. Major risk factors for zoonotic transmission of HEV include contact with infected animals especially pigs and consumption of undercooked animal products $[4,7]$. High detection rates of HEV RNA in pigs at slaughter have been demonstrated in different countries with up to $41 \%$ in Canada, and up to $44 \%$ in the UK [8-11]. This places people like pig handlers and abattoir workers at high risk of infection [12].

Zoonotic subtypes of HEV have also been detected in other major livestock, such as sheep, goats and cattle
[13-15]. The role these species play in zoonotic transmission has not been extensively explored and is therefore not known whether these livestock species also serve as natural reservoirs or were accidentally infected by swine derived strains [16].

Waterborne transmission of Genotypes 1 and 2 are believed to be the main cause of HEV infection in endemic regions of Africa, including Ghana [11]. However, extensive knowledge of HEV types and their abundance in livestock species in Ghana and Sub-Saharan African is scarce [17] and as such the putative risk of zoonotic infection from livestock particularly swine in these regions have not been well understood. The purpose of this study was to determine the occurrence and diversity of $\mathrm{HEV}$ in major livestock species in a developing country.

\section{Materials and methods}

\section{Sample collection and RNA extraction}

Serum samples from four major domestic livestock namely cattle, sheep, goats and swine were collected from Kumasi in the Ashanti region of Ghana in December, 2011 (Fig. 1) [18].

Blood was collected by venipuncture from swine, goats, sheep, and cattle into clot activation tubes by veterinary officers and centrifuged the same day to obtain

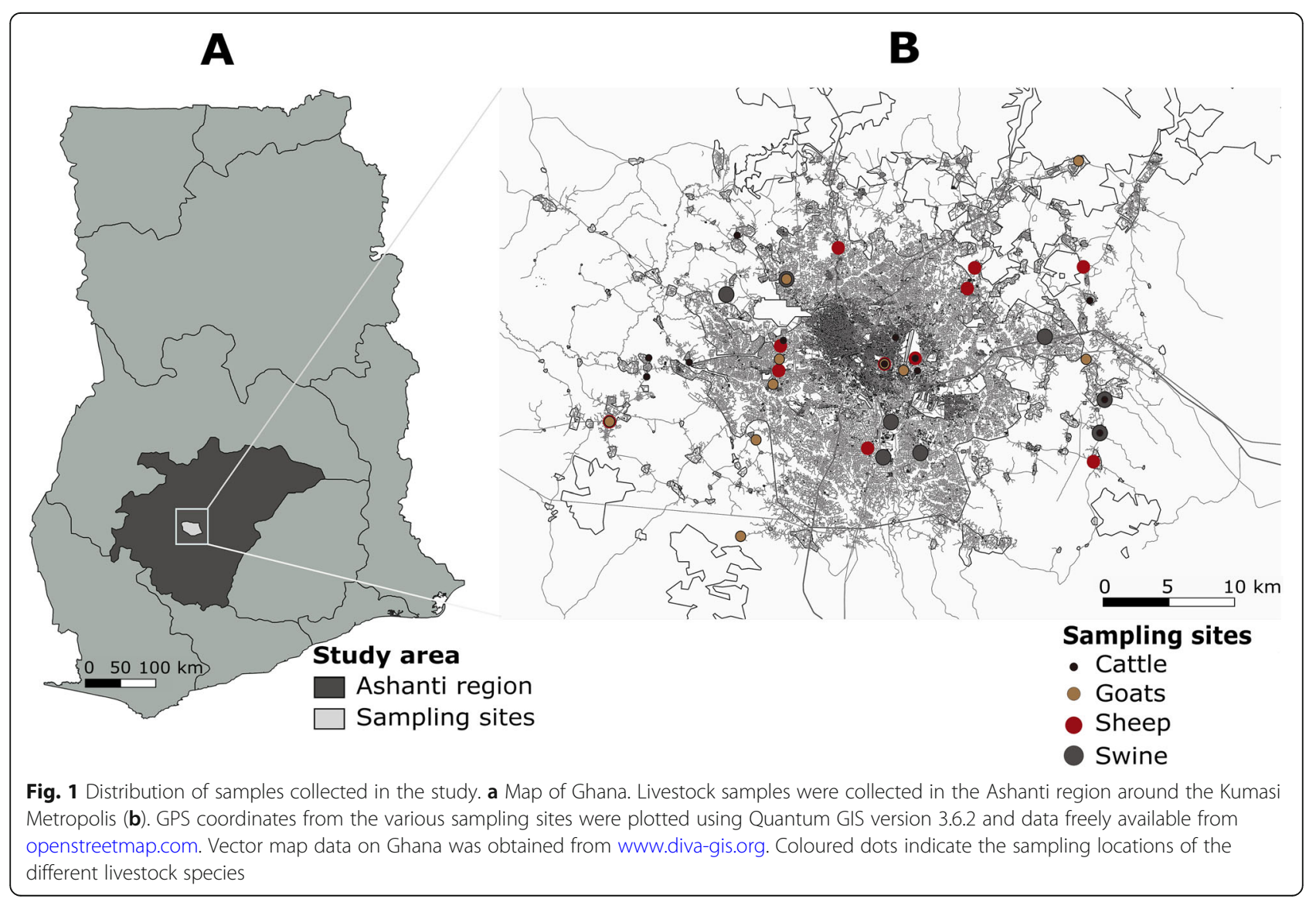


serum. Serum was stored at $-20^{\circ} \mathrm{C}$ until testing. Viral RNA was extracted from serum in pools of six with a total starting volume of $120 \mu \mathrm{l}$ using the MagNaPure96 nucleic acid extraction system (Roche Diagnostics Ltd., Risch-Rotkreuz, Switzerland) with the Viral NA Small Volume Kit. Elution volume was $100 \mu \mathrm{l}$.

\section{HEV-RNA detection and complete genome characterization}

Detection and sequencing of HEV-RNA was done as previously described [19]. Briefly, we applied a heminested reverse transcriptase (RT)-PCR using broadly reactive primers targeting a 338-nucleotide fragment of the RNA-dependent RNA polymerase (RdRp) gene of HEV with the Superscript III one-step RT-PCR kit (Thermo Fischer, MA, USA). All pools that tested positive by RT-PCR were resolved by testing the component samples individually. Quantification of viral RNA in positive samples was performed by real-time RT PCR as described previously [20, 21]. Standard curve generation for quantification was done using the World Health Organization International Standard for HEV [22].

The complete genome of one representative swine HEV from Ghana was obtained using hemi-nested RTPCR assays targeting overlapping regions of HEV-3 followed by Sanger sequencing (Microsynth Seqlab, Göttingen, Germany). Oligonucleotides and protocols used for the whole genome sequence generation were published by our group elsewhere [23].

\section{Serological testing}

To investigate past HEV exposure of pigs, all pig sera were tested by a commercial Anti-HEV IgG ELISA (PrioCHECK ${ }^{\oplus} \mathrm{HEV}$ Ab porcine ELISA kit; Thermo Fischer, MA, US) according to manufacturer's instructions. Briefly, buffer-diluted serum samples were incubated for $1 \mathrm{~h}$ at $37^{\circ} \mathrm{C}$ followed by conjugate incubation for $30 \mathrm{~min}$ also at $37^{\circ} \mathrm{C}$. Detection was done with Chromogenic TMB for $30 \mathrm{~min}$ at $22^{\circ} \mathrm{C}$.

For antibody testing of HEV-RNA-negative livestock species, a species-independent Anti-HEV ELISA capable of capturing total antibodies (IgG, IgM and IgA) (DRG Instruments $\mathrm{GmbH}$. Marburg, Germany) was used according to manufacturer's instructions. Positive outcomes were confirmed by serum IgG detection using a more specific recombinant, indirect, immunofluorescence assay (IFA) based on transfected African green monkey kidney cells (Vero B4) expressing a truncated HEV gt 7 capsid. All sera were tested at a dilution of 1 : 80. Secondary antibody detection for cattle, pigs, sheep and goats was done using Alexa Fluor 488-conjugted goat anti-bovine, goat anti-swine, donkey anti-sheep, and donkey anti-goat antibodies (Dianova $\mathrm{GmbH}$,
Hamburg, Germany) which have been shown previously to work for these species [24, 25].

\section{Data analysis}

Descriptive and inferential statistical analysis were performed using $\mathrm{R}$ statistical package version 3.6.0 ( $\mathrm{R}$ Core Team, Vienna, Austria). Multiple sequence alignments were performed as translation alignments using Geneious Prime 2019 (https://www.geneious.com). Recombination analyses were made using RDP4 [26].

Phylogenetic analyses was done by Bayesian inference with Bayesian Evolutionary Analysis by Sampling Trees (BEAST) [27] programme version 1.10.4 using a General time reversible nucleotide substitution model with a Gamma distribution across sites and proportion of invariable sites. A Markov chain Monti Carlo sampling approach with a chain length of 10,000,000 sampled every 1000 steps and the default constant size coalescent population model was used. Final trees were annotated and visualized with TreeAnnotator and FigTree from the same BEAST package.

Subtyping of the full genome sequence was done by phylogenetic comparison with proposed full genome subtypes from other studies.

\section{Results}

\section{Samples collected}

A total of 420 samples were available from cattle $(n=$ $105)$, goats $(n=124)$, swine $(n=89)$ and sheep $(n=102)$. For cattle, goats, and sheep, majority of the individual animals were more than 1 year old. However, for pigs, majority of the sampled animals were below 1 year (Table 1). For all species, more female animals than males were sampled with a combined proportion of $67.4 \%$ (Table 1).

\section{Testing for HEV RNA and antibodies}

RT-PCR testing of all livestock serum samples, resulted in 9 swine serum samples identified to be positive for HEV viral RNA, representing $10.1 \%$ of the collected swine samples. Pigs sampled in 3 of the 8 swine sampling

Table 1 Characteristics of samples collected in the study

\begin{tabular}{|c|c|c|c|c|c|}
\hline & \multicolumn{4}{|c|}{ Livestock Sampled (N, \%) } & \multirow[b]{2}{*}{$\begin{array}{l}\text { Total } \\
(420)\end{array}$} \\
\hline & $\begin{array}{l}\text { Cattle } \\
(105)\end{array}$ & $\begin{array}{l}\text { Goats } \\
(124)\end{array}$ & $\begin{array}{l}\text { Pigs } \\
(89)\end{array}$ & $\begin{array}{l}\text { Sheep } \\
(102)\end{array}$ & \\
\hline \multicolumn{6}{|c|}{ Age categories } \\
\hline$<1$ year & $6(5.7)$ & $12(9.7)$ & $83(93.3)$ & $8(7.8)$ & $109(26.0)$ \\
\hline$>1$ year & $99(94.3)$ & $112(90.3)$ & $6(6.7)$ & $94(92.2)$ & $311(74.0)$ \\
\hline \multicolumn{6}{|l|}{ Sex } \\
\hline Male & $41(39.1)$ & $30(24.2)$ & $39(43.8)$ & $27(26.5)$ & $137(32.6)$ \\
\hline Female & $64(60.9)$ & $94(75.8)$ & $50(56.2)$ & 75 (73.5) & $283(67.4)$ \\
\hline
\end{tabular}

$N$ Number 
sites showed acute HEV infection. No other tested livestock species were found to be positive by the screening RT-PCR. To further estimate the importance of pigs as an HEV reservoir in the sampling region, we further investigated past HEV exposure of pigs to HEV. A total of 69 (77.5\%) swine samples from all sampling sites were found to be positive for HEV IgG antibodies by ELISA testing. Out of the 9 HEV-RNA positive samples, 8 were also seropositive; which indicates that the presence of IgG does not rule out the presence of HEV RNA and suggests that the detected antibodies might not provide sterile immunity. Swine ages ranged from 4 months to 36 months with a median age of 6 months. Seroprevalence and RNA detection rate didn't differ between the age groups of 6 months or younger and older than 6 months (Fisher's exact test; $p>0.9$ and $p>0.7$ respectively, Table 2 ).

Average viral load as determined by quantitative real time RT-PCR calibrated using the WHO standard for HEV Viral RNA concentrations was $1 \times 10^{5}$ (range $1.02 \times 10^{3}$ to $3.17 \times 10^{5}$ ) International Units per $\mathrm{mL}$ of serum (Table 3), with no statistically significant differences between age groups ( $\mathrm{T}$-test comparison of means, $t=1.4272, \mathrm{df}=7, p=0.1966$, Table 3).

Among the RNA-negative livestock species, 25 cattle, 13 sheep and 7 goats tested positive for HEV-antibodies using the species-independent ELISA, however only 2 positive outcomes in goats from the same sampling site were confirmed by the immunofluorescence assay (Fig. 2c and d). The performance of the IFA was assessed by the inclusion of a known camel positive sample (Fig. 2a) and two of the ELISA positive swine samples from this study all of which tested positive (Fig. 2e and f). The detection of both camel gt7 and pig gt3 confirms the capability of the IFA to detect antibodies to different genotypes of HEV which may be present in the different livestock species.

\section{Sequence analyses}

For all HEV-RNA positive samples, a 316-nucleotide fragment from the $\mathrm{RdRp}$ gene, within Open Reading

Table 2 Determination of associations between test outcomes and age categories of sampled pigs

\begin{tabular}{|c|c|c|c|c|}
\hline \multirow[t]{2}{*}{$\begin{array}{l}\text { Test } \\
\text { performed }\end{array}$} & \multirow[t]{2}{*}{$\begin{array}{l}\text { Outcome } \\
\text { N (\%) }\end{array}$} & \multicolumn{2}{|l|}{$\begin{array}{l}\text { Age group } \\
\mathrm{N}(\%)\end{array}$} & \multirow[t]{2}{*}{$\begin{array}{l}\text { Fisher's exact } \\
\text { test ( } P \text { value) }\end{array}$} \\
\hline & & $\leq 6$ months & $>6$ months & \\
\hline \multirow[t]{2}{*}{ HEV RNA } & $\begin{array}{l}\text { Positive } \\
(9,10.1 \%)\end{array}$ & $6(10.7 \%)$ & $3(9.0 \%)$ & $>0.9$ \\
\hline & $\begin{array}{l}\text { Negative } \\
(80,89.9 \%))\end{array}$ & 50 (89.3\%) & 30 (90.9\%) & \\
\hline \multirow[t]{2}{*}{ HEV IgG } & $\begin{array}{l}\text { Positive } \\
(69,77.5 \%)\end{array}$ & $44(78,6 \%)$ & 25 (75.8\%) & 0.7964 \\
\hline & $\begin{array}{l}\text { Negative } \\
(20,22.5 \%)\end{array}$ & $12(21.4 \%)$ & $8(24.2 \%)$ & \\
\hline
\end{tabular}

Table 3 Serum viral loads of HEV positive pigs and comparison between age categories

\begin{tabular}{|c|c|c|c|}
\hline Pig sample & \multicolumn{3}{|c|}{ Viral Load (IU/mL) } \\
\hline GHS 02 & \multicolumn{3}{|c|}{$3.17 \times 10^{5}$} \\
\hline GHS 07 & \multicolumn{3}{|l|}{$8.15 \times 10^{4}$} \\
\hline GHS 10 & \multicolumn{3}{|l|}{$5.05 \times 10^{4}$} \\
\hline GHS 74 & \multicolumn{3}{|l|}{$9.14 \times 10^{4}$} \\
\hline GHS 78 & \multicolumn{3}{|l|}{$1.37 \times 10^{5}$} \\
\hline GHS 81 & \multicolumn{3}{|l|}{$2.07 \times 10^{5}$} \\
\hline GHS 86 & \multicolumn{3}{|l|}{$1.02 \times 10^{3}$} \\
\hline GHS 90 & \multicolumn{3}{|l|}{$8.00 \times 10^{3}$} \\
\hline GHS 91 & \multicolumn{3}{|l|}{$1.05 \times 10^{5}$} \\
\hline Age group in months & Minimum & Mean & Maximum \\
\hline$<6$ & $8.00 \times 10^{3}$ & $1.27 \times 10^{5}$ & $3.17 \times 10^{5}$ \\
\hline$>6$ & $1.02 \times 10^{3}$ & $4.76 \times 10^{4}$ & $9.14 \times 10^{4}$ \\
\hline All & $1.02 \times 10^{3}$ & $1.00 \times 10^{5}$ & $3.17 \times 10^{5}$ \\
\hline
\end{tabular}
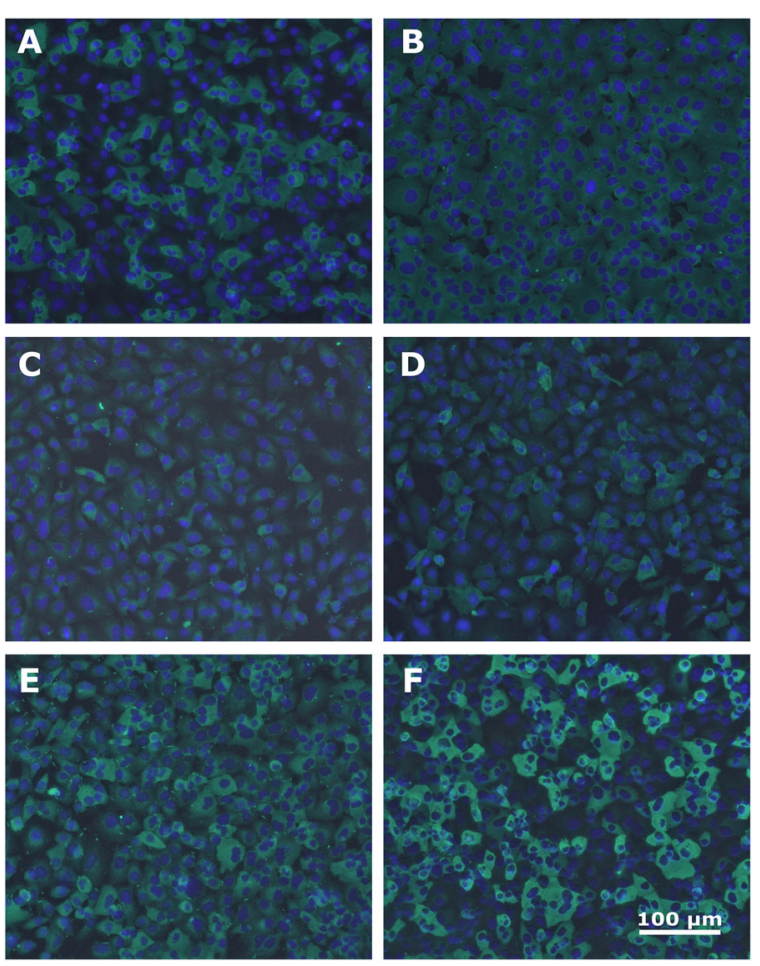

Fig. 2 Immunofluorescent detection of HEV IgG antibodies in livestock species. a depicts an ELISA positive camel sample showing a positive signal. $\mathbf{b}$ shows a cattle sample from this study with a negative outcome. $\mathbf{c}$ and $\mathbf{d}$ depict IFA-positive goat samples obtained in this study and (e and $\mathbf{f}$ ) show two ELISA positive pigs from this study also showing positive IFA signals. Cell nuclei were stained with DAPI and are shown as dark blue and the bright green impressions around the nuclei represent fluorescent antibody-antigen complexes 


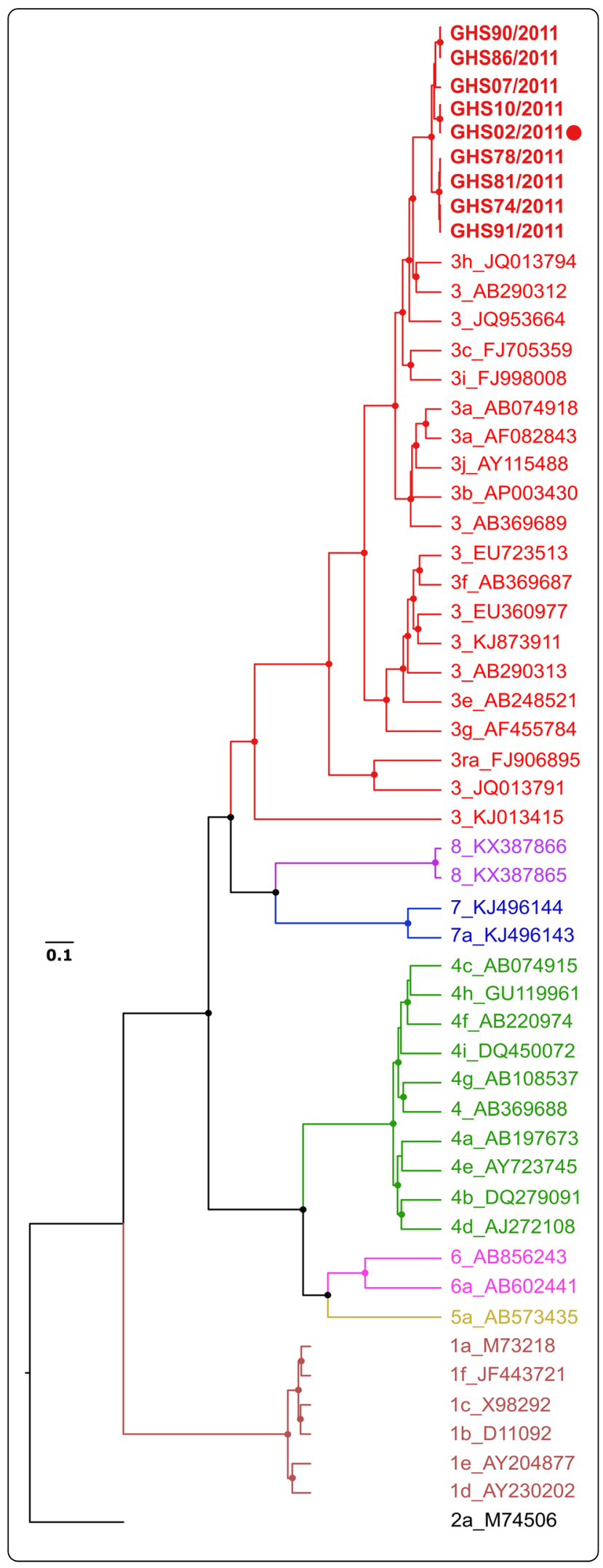

Fig. 3 Phylogenetic analysis of sequences obtained in the study in comparison to reference sequences from GenBank. The figure depicts clustering of the various genotypes of HEV with genotype 1 shown in brown, genotype 3 in red, genotype 4 in green, genotype 5 in yellow, genotype 6 shown in purple, genotypes 7 in blue and genotype 8 in violet. Circular nodes represent branching with posterior probabilities greater than 0.95 . The tree was rooted with a genotype 2 sequence shown in black. The sequences obtained in this study are identified by sequence specific names in bold type font and clustered with other genotype 3 viruses. The full genome sequence is indicated by a red dot

Frame (ORF) 1 of HEV, was sequenced. A phylogenetic analyses together with reference sequences defined by Smith et al. [2] confirmed all HEV strains from this study to belong to one distinct monophyletic group within HEV gt3 (Fig. 3). For detailed genomic characterization and to provide an avenue for comparison with other studies on African HEV sequences targeting different regions of the genome, we selected one sample with the highest RNA concentration for fulllength genome sequencing. The obtained HEV sequence showed typical genome organization for Orthohepevirus A strains, including the presence of short $3^{\prime}$ and $5^{\prime}$ untranslated regions at the genome termini and presence of three predicted open reading frames (ORF1, ORF2, and ORF3). There was no evidence hinting to recombination of the Ghanaian pig HEV strain with other Orthohepevirus species or the known Orthohepevirus A subtypes. A phylogenetic analysis using HEV gt3 subtypes proposed by smith et al., [2] Vina-Rodriguez et al., [28] Wang et al., [29] and De Sabato et al., [30] showed the full genome sequence from this study appeared to belong to the subtype $3 \mathrm{~h}$ (Fig. 4). All sequences were submitted to GenBank and assigned accession numbers MN714358 to MN714366.

The Ghanaian pig HEV shares an $87.5 \%$ nucleotide identity averaged over the full genome with the most closely related sequence strain from Mongolia (GenBank Acc No: AB290312) followed by a sequence from France (86.7\%, GenBank Acc No: JQ013794). Partial sequences obtained in the study had sequence identities ranging between 87.7 to $89.9 \%$ and with the exception of GHS07 which was also found to be most closely related to the sequence from Mongolia, all other partial sequences were found to be most closely related to a sequence from Germany (Acc No: FJ998008) (Table 4). A partial section of the full genome in the same region as the other partial sequences was also found to be most closely related to the sequence from Germany. This hints to the likelihood of all other partial sequences being more closely related to the sequence from Mongolia at the full genome level.

To test if all African HEV gt3 sequences form a single monophyletic group and might stem from a common 


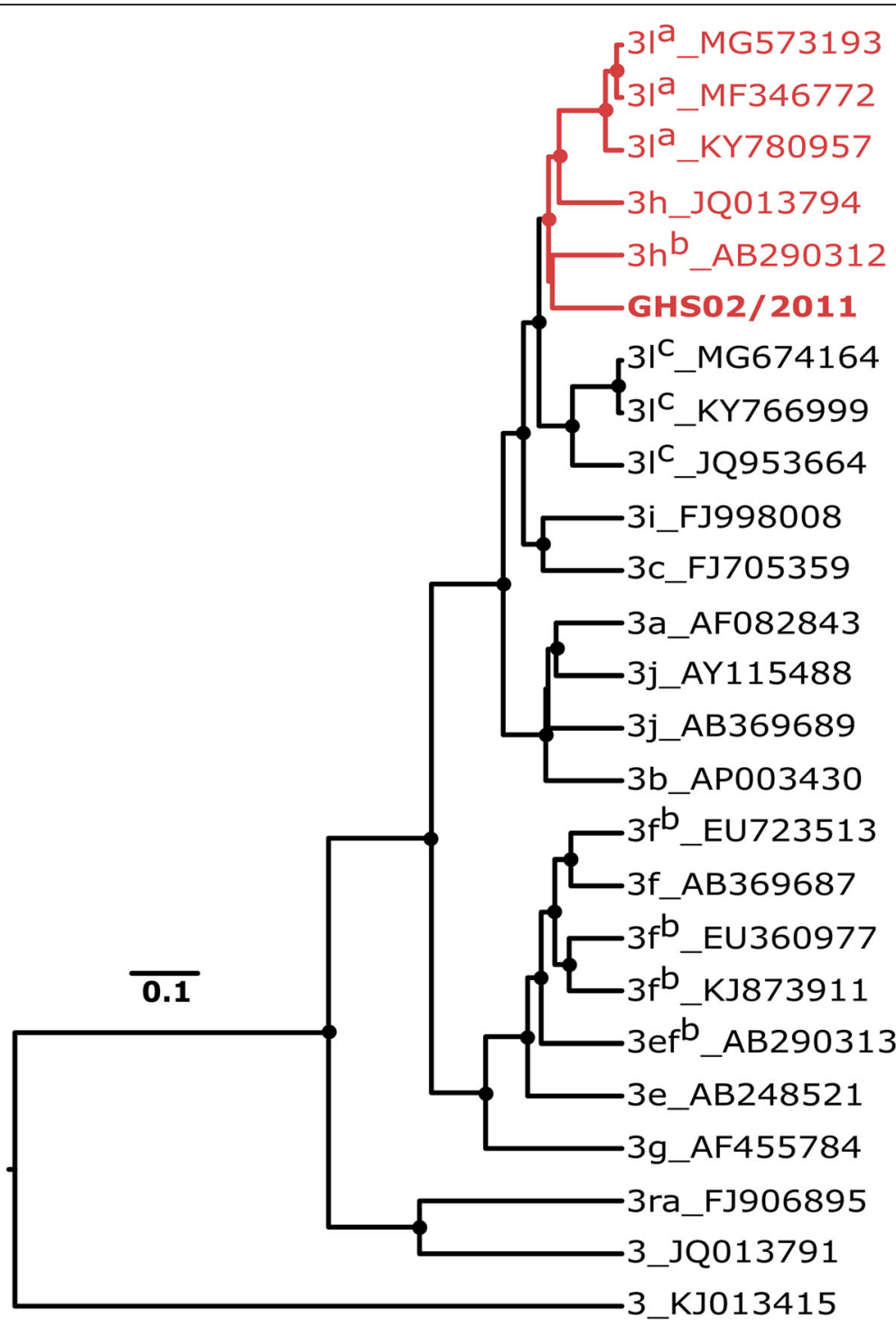

Fig. 4 Phylogenetic analysis of the full-length sequence obtained in the study in comparison to proposed full length genotype 3 subtypes. The figure depicts clustering of various genotype 3 subtypes. Circular nodes represent branching with posterior probabilities greater than 0.95 . Subtypes indicated are as proposed by Smith et al., [2]. Sequences included by Smith et al., but with unassigned subtypes were assigned subtypes (indicated by superscripts) proposed by Wang et al. (a) [29] Vina-Rodriguez et al., (b) [28] and De Sabato et al., (c) [30]. The sequence obtained in this study was identified by a bold type font and clustered with subtype $3 \mathrm{~h}$ and $3 \mathrm{l}^{\mathrm{a}}$ sequences

Table 4 Sequence identities of partial sequences obtained in the study

\begin{tabular}{lll}
\hline Sequence ID & Sequence Identity (\%) & Most closely related reference sequence (Accession number) \\
\hline GHS07 & 88.6 & AB290312 \\
GHS10 & 88.3 & FJ998008 \\
GHS74 & 89.9 & FJ998008 \\
GHS78 & 89.6 & FJ998008 \\
GHS81 & 89.2 & FJ998008 \\
GHS86 & 87.7 & FJ998008 \\
GHS90 & 87.7 & FJ998008 \\
GHS91 & 89.6 & FJ998008 \\
\hline
\end{tabular}


ancestor, phylogenetic analyses of the $\mathrm{RdRp}$ region within the ORF1 and the capsid region within ORF2 were done by adding all publicly available sequences from Africa available in GenBank (as of 15th November 2019) to our analyses. Although sequences from Cameroon, Ghana, Burkina Faso and Madagascar did share a most common recent ancestor in capsid or RdRp based phylogeny (Figure S1 to S2) other African HEV sequences from Nigeria, Democratic Republic of the Congo, Uganda, and São Tomé and Príncipe did not cluster in the same monophyletic group and intermixed with other non-African HEV strains (Figure S1 to S2).

\section{Discussion}

Hepatitis E virus is known to be circulating in Ghana with previous studies focused on humans reporting seroprevalences in people exposed to livestock and immunocompromised individuals [31, 32]. In Ghana, HEV infections in pregnant women has been found to be a serious cause of perinatal morbidity and mortality [33]. Exposure to HEV among pigs and humans appears to significantly vary between regions with one study estimating around $4.6 \%$ among blood donors in the Ashanti region [34] but up to $58 \%$ among community members and $88 \%$ in pigs in the Upper East region as against the $77.5 \%$ in pigs observed in this study [35]. Among the viral causes of hepatitis in Ghana, HEV appears to be second only to Hepatitis B [36]. Data on prevalence and knowledge of circulating genotypes of HEV in the livestock population is however widely scarce due to lack of studies reporting sequence information [37].

Beyond Ghana, HEV has been found in domestic and wild animals from different parts of the world [38]. Without totally excluding domestic livestock like sheep, goats, cows and equids, swine have been found to be the main source of human infections worldwide [12-15, 37, 39, 40]. In line with these findings, cattle, sheep, and goats were not found to harbour any active HEV infections and also exhibited a low level of previous exposure in our study. The fact that swine samples from all sampling sites were found to be positive for HEV IgG antibodies suggests a high infection rate in pigs independent of the farm of origin and are consistent with reports of HEV infection in pigs in Europe, Asia, and the Americas [11], hinting to a similar epidemiology of HEV gt3 in pigs worldwide.

Detection of HEV RNA among swine can be considered a measure of the risk to people in contact with swine or swine products [41]. The detection rate however varies based on organs or tissues tested with the detection rate of the virus in blood generally lower than that from other organs like liver or in faeces and caecal contents [42-44].

Detection rate in blood in this study was higher than in other studies conducted in Asia, Europe and South
America [42, 45-48] possibly as a consequence of differences in husbandry practices [49] between sub-Saharan Africa and other parts of the world. However, the average HEV viral load determined in this study was within the range of another study conducted in the United Kingdom which found a range from as low as below $100 \mathrm{IU} / \mathrm{mL}$ to as high as $10^{6} \mathrm{IU} / \mathrm{mL}$ in plasma at slaughter [42]. Studies comparing infective doses of the different HEV strains are lacking [6] however as a general indicator for risk of zoonotic transmission, the viral load has been found to influence the potential of getting infected [12].

Age of detection of viremia in swine has also been found to range from 2 to 6 months in previous studies from different parts of the world $[10,50,51]$ but was slightly higher in this study. As the age of slaughter is mostly below 1 year in many parts of the world including Ghana, the risk of infection therefore also appears comparable worldwide [10, 52-54]. Adjusting slaughter age to periods after this may help reduce the risk of human infection, as also suggested in another study from France that found a lower HEV RNA prevalence in pigs older than 6 months as compared to those that were 3-4 months old [55].

Prevalence of seroconverted pigs reported varies widely and are difficult to compare due to variations in sensitivities of testing methods. However the antibody detection rate reported in this study was comparable to those from other studies worldwide [11].

In developed countries, eating raw or undercooked pork is a major cause of zoonotic transmission of HEV [56]. In Ghana, consumption of raw pork is not common due to cultural consumption norms. The main risk of zoonotic transmission is therefore more likely to be due to exposure to pigs and pig products in occupationally exposed people like slaughterhouse workers. This risk of zoonotic transmission of HEV gt3 from pigs to humans is underlined by the remarkable RNA detection rate of $10 \%$ in serum and the high virus concentration in these samples.

The fact that sequences from this study were found to be most closely related to genotype 3 sequences from other West African countries (Cameroon and Burkina Faso) might hint to a common origin of some African swine genotype $3 \mathrm{HEV}$ viruses. However, the clustering of African gt3 HEV viruses in different monophyletic groups challenges this hypothesis. This inconsistency can however be explained by the fact that trade of live pigs and their HEV strains is common and pigs were regularly imported into Africa from Europe and Asia in previous times [57].

\section{Conclusions}

In summary, HEV genotype 3 appears to be the main genotype circulating in pigs from Ghana with similar 
infection dynamics to those observed in other parts of the world. The geographic origin of these viruses could be from within sub-Saharan Africa but more studies reporting sequences are needed to assess this. Viral loads in slaughter age pigs in this study point to a high risk of infection among slaughterhouse workers or people with close contact to pigs in Ghana.

\section{Supplementary information}

Supplementary information accompanies this paper at https://doi.org/10. 1186/s42522-020-00018-3.

Additional file 1: Figure S1. Cladogram based on partial and fulllength sequences from the HEV gt3 capsid region. Figure S2. Cladogram based on partial and full-length sequences from the HEV gt3 RdRp region.

\section{Abbreviations}

BEAST: Bayesian Evolutionary Analysis by Sampling Trees; ELISA: EnzymeLinked Immunosorbent Assay; GIS: Geographic Information System; GPS: Global Positioning System; GT3: Genotype 3; HEV: Hepatitis E Virus; ICTV: International Committee on Taxonomy of Viruses; IFA: Immunofluorescence assay; IgA: Immunoglobulin A; IgG: Immunoglobulin G; IgM: Immunoglobulin M; IU: International Units; MA: Massachusetts; mL: Millilitre; NA: Nucleic acid; ORF: Open Reading Frame; PCR: Polymerase Chain Reaction; RDP4: Recombination Detection Program 4; RdRp: RNA-dependent RNA polymerase; RNA: Ribonucleic Acid; RT: Reverse Transcriptase; TMB: 3,3',5,5'-Tetramethylbenzidine; UK: United Kingdom; USA: United States of America; WHO: World Health Organization

\section{Acknowledgments}

We thank Monika Eschbach-Bludau, Tobias Bleicker and Sebastian Brünink for their excellent assistance.

\section{Authors' contributions}

VMC, JFD, CD, YAS, RP conceived, designed, and coordinated the study. DD, $\mathrm{TB}, \mathrm{AS}, \mathrm{RW}, \mathrm{WT}, \mathrm{SO}, \mathrm{BE}, \mathrm{RF}, \mathrm{JFD}$ were involved in collection of samples from livestock animals and data collection. PED, VMC did virological testing and sequencing and developed the first draft of the manuscript. All authors contributed to writing and finalising the manuscript and agreed to submit for publication. All authors reviewed the data. The author(s) read and approved the final manuscript.

\section{Funding}

This work was in part financially supported by a grant from the German Federal Ministry of Health (grant ZMVI1-2518FSB705) to VMC, and from Deutsche Forschungsgemeinschaft (DR 772/12-1) to YAS and CD. This publication is part of the PANDORA-ID-NET (EDCTP Reg/Grant RIA2016E-1609), funded by the European and Developing Countries Clinical Trials Partnership (EDCTP2) programme which is supported under Horizon 2020, the European Union's Framework Programme for Research and Innovation. The views and opinions of authors expressed herein do not necessarily state or reflect those of EDCTP.

\section{Availability of data and materials}

Data generated or analysed during this study are included in this published article and its supplementary information files. Sequences are available via NCBI GenBank. Further supporting data if required are available from the corresponding author on reasonable request.

\section{Ethics approval and consent to participate}

Permission for livestock sampling was obtained from the livestock division of the Ghana Forestry Commission and livestock owners.

\section{Consent for publication}

Not applicable.

\section{Competing interests}

The authors declare that they have no competing interests.

\section{Author details}

${ }^{1}$ Charité-Universitätsmedizin Berlin, Humboldt-Universität zu Berlin, Berlin Institute of Health, Institute of Virology, Berlin, Germany. ${ }^{2}$ Kumasi Centre for Collaborative Research in Tropical Medicine, Kumasi, Ghana. ${ }^{3}$ Ghana Veterinary Service, Kumasi, Ghana. ${ }^{4}$ School of Veterinary Medicine, Kwame Nkrumah University of Science and Technology, Kumasi, Ghana. ${ }^{5}$ Department of Theoretical and Applied Biology, Kwame Nkrumah University of Science and Technology, Kumasi, Ghana. ${ }^{6}$ Institute of Virology, University of Bonn Medical Centre, Bonn, Germany. ${ }^{7}$ Department of Wildlife and Range Management, Kwame Nkrumah University of Science and Technology, Kumasi, Ghana. ${ }^{8}$ Department of Clinical Microbiology, Kwame Nkrumah University of Science and Technology, Kumasi, Ghana. ${ }^{9}$ German Centre for Infection Research, Berlin, Germany.

Received: 10 January 2020 Accepted: 5 May 2020

Published online: 20 July 2020

\section{References}

1. Purdy MA, Harrison TJ, Jameel S, Meng XJ, Okamoto H, Van der Poel WHM, et al. ICTV virus taxonomy profile: Hepeviridae. J General Virol. 2017;98(11): 2645-6.

2. Smith DB, Simmonds $P$, Izopet J, Oliveira-Filho EF, Ulrich RG, Johne R, et al. Proposed reference sequences for hepatitis E virus subtypes. J Gen Virol. 2016;97(3):537-42.

3. Woo PC, Lau SK, Teng JL, Cao KY, Wernery U, Schountz T, et al. New hepatitis E virus genotype in Bactrian camels, Xinjiang, China, 2013. Emerg Infect Dis. 2016;22(12):2219-21.

4. Denner J. Hepatitis E virus (HEV)-the future. Viruses. 2019;11:3.

5. Rasche A, Sander AL, Corman VM, Drexler JF. Evolutionary biology of human hepatitis viruses. J Hepatol. 2019:70(3):501-20.

6. Kamar N, Dalton HR, Abravanel F, Izopet J. Hepatitis E virus infection. Clin Microbiol Rev. 2014:27(1):116-38.

7. Guillois Y, Abravanel F, Miura T, Pavio N, Vaillant V, Lhomme S, et al. High proportion of asymptomatic infections in an outbreak of hepatitis $E$ associated with a spit-roasted piglet, France, 2013. Clin Infect Dis. 2016;62(3): 351-7.

8. Crossan C, Grierson S, Thomson J, Ward A, Nunez-Garcia J, Banks M, et al. Prevalence of hepatitis E virus in slaughter-age pigs in Scotland. Epidemiol Infect. 2015;143(10):2237-40.

9. Krog JS, Larsen LE, Breum SO. Tracing hepatitis E virus in pigs from birth to slaughter. Front Vet Sci. 2019;6:50.

10. Leblanc D, Ward P, Gagne MJ, Poitras E, Muller P, Trottier YL, et al. Presence of hepatitis $E$ virus in a naturally infected swine herd from nursery to slaughter. Int J Food Microbiol. 2007;117(2):160-6.

11. Pavio N, Doceul V, Bagdassarian E, Johne R. Recent knowledge on hepatitis E virus in Suidae reservoirs and transmission routes to human. Vet Res. 2017; 48(1):78.

12. Ukuli AQ, Mugimba KK. Seroprevalence of hepatitis $E$ in swine abattoir workers. Afr Health Sci. 2017;17(4):1022-8.

13. Li S, Liu M, Cong J, Zhou Y, Miao Z. Detection and characterization of hepatitis $E$ virus in goats at slaughterhouse in Tai'an region, China. Biomed Res Int. 2017:2017:3723650

14. Huang F, Li Y, Yu W, Jing S, Wang J, Long F, et al. Excretion of infectious hepatitis $E$ virus into milk in cows imposes high risks of zoonosis. Hepatology (Baltimore, Md). 2016;64(2):350-9.

15. Sarchese V, Di Profio F, Melegari I, Palombieri A, Sanchez SB, Arbuatti A, et al. Hepatitis E virus in sheep in Italy. Transbound Emerg Dis. 2019;66(3): 1120

16. Sander AL, Corman VM, Lukashev AN, Drexler JF. Evolutionary origins of enteric hepatitis viruses. Cold Spring Harb perspect Med. 2018;8:12.

17. Smith DB, Simmonds P. Classification and genomic diversity of Enterically transmitted hepatitis viruses. Cold Spring Harb Perspect Med. 2018;8:9.

18. Corman VM, Grundhoff A, Baechlein C, Fischer N, Gmyl A, Wollny R, et al. Highly divergent hepaciviruses from African cattle. J Virol. 2015;89(11):5876-82.

19. Drexler JF, Seelen A, Corman VM, Fumie Tateno A, Cottontail V, Melim Zerbinati $R$, et al. Bats worldwide carry hepatitis $E$ virus-related viruses that form a putative novel genus within the family Hepeviridae. J Virol. 2012; 86(17):9134-47. 
20. Giron-Callejas A, Clark G, Irving WL, McClure CP. In silico and in vitro interrogation of a widely used HEV RT-qPCR assay for detection of the species Orthohepevirus a. J Virol Methods. 2015;214:25-8.

21. Jothikumar N, Cromeans TL, Robertson BH, Meng XJ, Hill VR. A broadly reactive one-step real-time RT-PCR assay for rapid and sensitive detection of hepatitis E virus. J Virol Methods. 2006;131(1):65-71.

22. Baylis SA, Blümel J, Mizusawa S, Matsubayashi K, Sakata H, Okada Y, et al. World Health Organization International Standard to harmonize assays for detection of hepatitis E virus RNA. Emerg Infect Dis. 2013;19(5):729-35.

23. Corman VM, Hilgensloh L, Voigt U, Marklewitz M, Siebert U, Drosten C, et al. Hepatitis E virus infection in European Brown hares, Germany, 2007-2014. Emerg Infect Dis. 2019;25(6):1233-5.

24. Burimuah V, Sylverken A, Owusu M, El-Duah P, Yeboah R, Lamptey J, et al. Sero-prevalence, cross-species infection and serological determinants of prevalence of bovine coronavirus in cattle, sheep and goats in Ghana. Vet Microbiol. 2020;241:108544.

25. Binger T, Annan A, Drexler JF, Müller MA, Kallies R, Adankwah E, et al. A novel rhabdovirus isolated from the straw-colored fruit bat Eidolon helvum, with signs of antibodies in swine and humans. J Virol. 2015;89(8):4588-97.

26. Martin DP, Murrell B, Golden M, Khoosal A, Muhire B. RDP4: detection and analysis of recombination patterns in virus genomes. Virus Evol. 2015;1(1): vev003.

27. Drummond AJ, Suchard MA, Xie D, Rambaut A. Bayesian phylogenetics with BEAUti and the BEAST 1.7. Mol Biol Evol. 2012;29(8):1969-73.

28. Vina-Rodriguez A, Schlosser J, Becher D, Kaden V, Groschup MH, Eiden M. Hepatitis E virus genotype 3 diversity: phylogenetic analysis and presence of subtype 3b in wild boar in Europe. Viruses. 2015;7(5):2704-26.

29. Wang B, Harms D, Hofmann J, Ciardo D, Kneubühl A, Bock C-T. Identification of a novel hepatitis $E$ virus genotype 3 strain isolated from a chronic hepatitis $\mathrm{E}$ virus infection in a kidney transplant recipient in Switzerland. Genome Announc. 2017;5(20):e00345-17.

30. De Sabato L, Lemey P, Vrancken B, Bonfanti L, Ceglie L, Vaccari G, et al. Proposal for a new subtype of the zoonotic genotype 3 hepatitis $E$ virus: HEV-3l. Virus Res. 2018;248:1-4.

31. Adjei AA, Tettey Y, Aviyase JT, Adu-Gyamfi C, Obed S, Mingle JA, et al. Hepatitis $E$ virus infection is highly prevalent among pregnant women in Accra, Ghana. Virol J. 2009;6:108.

32. Adjei AA, Tettey Y, Aviyase JT, Adu-Gyamfi C, Mingle JA, Nartey ET. Unexpected elevated alanine aminotransferase, aspartate aminotransferase levels and hepatitis $E$ virus infection among persons who work with pigs in Accra, Ghana. Virol J. 2010;7:336.

33. Bonney JH, Kwame-Aryee RA, Obed S, Tamatey AA, Barnor JS, Armah NB, et al. Fatal hepatitis $E$ viral infection in pregnant women in Ghana: a case series. BMC Res Notes. 2012:5:478.

34. Meldal BH, Sarkodie F, Owusu-Ofori S, Allain JP. Hepatitis E virus infection in Ghanaian blood donors - the importance of immunoassay selection and confirmation. Vox Sang. 2013;104(1):30-6.

35. Majekodunmi AO, Addo HO, Bagulo H, Bimi L. Integrated value-chain and risk assessment of pig-related Zoonoses in Ghana. PLoS One. 2019;14(11): e0224918.

36. Owusu M, Bonney JK, Annan AA, Mawuli G, Okyere K, Mutocheluh M, et al. Aetiology of viral hepatitis among jaundiced patients presenting to a tertiary hospital in Ghana. PLoS One. 2018;13(9):e0203699.

37. Garcia-Bocanegra I, Rivero A, Caballero-Gomez J, Lopez-Lopez P, CanoTerriza D, Frias $M$, et al. Hepatitis $E$ virus infection in equines in Spain. Transbound Emerg Dis. 2019;66(1):66-71.

38. Sridhar S, Teng JLL, Chiu TH, Lau SKP, PCY W. Hepatitis E virus genotypes and evolution: emergence of camel hepatitis E variants. Int J Mol Sci. 2017; 18:4.

39. Raspor Lainscek P, Toplak I, Kirbis A. A comprehensive study of hepatitis E virus infection in pigs entering a slaughterhouse in Slovenia. Vet Microbiol. 2017;212:52-8

40. Antia RE, Adekola AA, Jubril AJ, Ohore OG, Emikpe BO. Hepatitis E virus infection seroprevalence and the associated risk factors in animals raised in Ibadan, Nigeria. J Immunoass Immunochem. 2018;39(5):509-20.

41. Kamar N, Izopet J, Pavio N, Aggarwal R, Labrique A, Wedemeyer $\mathrm{H}$, et al. Hepatitis E virus infection. Nat Rev Dis Primers. 2017;3:17086.

42. Grierson S, Heaney J, Cheney T, Morgan D, Wyllie S, Powell L, et al. Prevalence of hepatitis $E$ virus infection in pigs at the time of slaughter, United Kingdom, 2013. Emerg Infect Dis. 2015;21(8):1396-401.
43. Huang FF, Haqshenas G, Guenette DK, Halbur PG, Schommer SK, Pierson $F W$, et al. Detection by reverse transcription-PCR and genetic characterization of field isolates of swine hepatitis $E$ virus from pigs in different geographic regions of the United States. J Clin Microbiol. 2002; 40(4):1326-32.

44. Leblanc D, Poitras E, Gagne MJ, Ward P, Houde A. Hepatitis E virus load in swine organs and tissues at slaughterhouse determined by real-time RTPCR. Int J Food Microbiol. 2010;139(3):206-9.

45. Choi IS, Kwon HJ, Shin NR, Yoo HS. Identification of swine hepatitis E virus (HEV) and prevalence of anti-HEV antibodies in swine and human populations in Korea. J Clin Microbiol. 2003:41(8):3602-8.

46. Lee SH, Kang SC, Kim DY, Bae JH, Kim JH. Detection of swine hepatitis E virus in the porcine hepatic lesion in Jeju Island. J Vet Sci. 2007;8(1):51-5.

47. de Campos CG, Silveira S, Schenkel DM, Carvalho H, Teixeira EA, de Almeida SM, et al. Detection of hepatitis E virus genotype 3 in pigs from subsistence farms in the state of Mato Grosso, Brazil. Comp Immunol Microbiol Infect Dis. 2018;58:11-6.

48. Lipej Z, Novosel D, Vojta L, Roic B, Simpraga M, Vojta A. Detection and characterisation of hepatitis $E$ virus in naturally infected swine in Croatia. Acta Vet Hung. 2013;61(4):517-28.

49. Rutjes SA, Bouwknegt M, van der Giessen JW, de Roda Husman AM, Reusken CB. Seroprevalence of hepatitis $E$ virus in pigs from different farming systems in the Netherlands. J Food Prot. 2014;77(4):640-2.

50. Takahashi M, Nishizawa T, Miyajima H, Gotanda Y, lita T, Tsuda F, et al. Swine hepatitis $E$ virus strains in Japan form four phylogenetic clusters comparable with those of Japanese isolates of human hepatitis $E$ virus. J Gen Virol. 2003;84(Pt 4):851-62.

51. Wu JC, Chen CM, Chiang TY, Tsai WH, Jeng WJ, Sheen IJ, et al. Spread of hepatitis E virus among different-aged pigs: two-year survey in Taiwan. J Med Virol. 2002;66(4):488-92

52. Forero JE, Gutierrez-Vergara C, Parra Suescun J, Correa G, Rodriguez B, Gutierrez LA, et al. Phylogenetic analysis of hepatitis $E$ virus strains isolated from slaughter-age pigs in Colombia. Infect Genet Evol. 2017:49:138-45.

53. Casas M, Cortes R, Pina S, Peralta B, Allepuz A, Cortey M, et al. Longitudinal study of hepatitis E virus infection in Spanish farrow-to-finish swine herds. Vet Microbiol. 2011;148(1):27-34.

54. Laryea M, Emikpe B, Attoh-Kotoku V, Omotosho O, Asare D, Asenso N, et al. The occurrence of gastric lesions in slaughtered pigs at the Kumasi abattoir, GHANA. Bangladesh J Vet Med. 2016;14(1):85-91.

55. Capai L, Maestrini O, Casabianca F, Villechenaud N, Masse S, Bosseur F, et al. Drastic decline of hepatitis $E$ virus detection in domestic pigs after the age of 6 months, Corsica, France. Transbound Emerg Dis. 2019;66(6):2462.

56. Hoofnagle JH, Nelson KE, Purcell RH. Hepatitis e. N Engl J Med. 2012;367(13): 1237-44.

57. Ministry of Food and Agriculture. Livestock development in Ghana, policies and strategies; 2004. (http://extwprlegs1.fao.org/docs/pdf/gha148233.pdf). Accessed 12 Dec 2019

\section{Publisher's Note}

Springer Nature remains neutral with regard to jurisdictional claims in published maps and institutional affiliations.

\section{Ready to submit your research? Choose BMC and benefit from:}

- fast, convenient online submission

- thorough peer review by experienced researchers in your field

- rapid publication on acceptance

- support for research data, including large and complex data types

- gold Open Access which fosters wider collaboration and increased citations

- maximum visibility for your research: over $100 \mathrm{M}$ website views per year

At $\mathrm{BMC}$, research is always in progress.

Learn more biomedcentral.com/submission 